\title{
Upaya Peningkatan Profesionalisme Karyawan Untuk Meningkatkan Kualitas Pelayanan Karyawan Abadi Hotel Jogja
}

\author{
Heni Widyaningsih \\ Akademi Pariwisata BSI Yogyakarta \\ Email : heni.hwh@bsi.ac.id
}

\begin{abstract}
Yogyakarta as one part of the State of Indonesia has considerable potential to participate in the development of tourism in Indonesia. In the midst of today's global competition it is important for every hotel employee to improve service in order to compete with other hotels. What the hotel management needs to do now is improve its quality through improving employee professionalism to make guests feel satisfied and loyal. Profession which is currently encouraged by Kemenpar in cooperation with Professional Certification Institution (LSP) to conduct competency test, one of them is hotel. The formulation of the problem that can be drawn from this research is how to improve the professionalism of employees to improve service quality at Abadi Hotel Jogja. The purpose of this study is to find out how efforts to increase the professionalism of employees to improve service quality at Abadi Hotel Jogja. The research method used in this research is descriptive qualitative research method. Efforts to increase the professionalism of employees at Abadi Hotel Jogja is by providing scholarships to the education of outstanding employees who are awarded beasisawa to continue D3 for the still high school certified, and scholarship to continue D4 / S1, held training held at Abadi Hotel Jogja that is UP selling training, skill, human resource development, Grooming, Attitude, Handling Complain, Leadership and Skill Communication, Making Bed, Step by step dusting procedure, How to clean the bathroom, How to vacuum swimming pool, How to prepare room boy cart, Entering the guest room, Check room status, How to clean glasses, How to clean the furniture, How to linen safety, How to pick up \& delivery guest laundry, Refresh billing system, application of Standard Operational Procedures (SOP) and action plan provided by experts in accordance with the field namely lecturers APMD, practitioners from Hyatt Hotel, TVRI, tourism experts, and intern from HRD and visit other hotels to study, as well as to implement competency certification for employees to determine that a person meets the requirements of the competencies established in cooperation with the Yogyakarta Tourism LSP.
\end{abstract}

Keywords: Employee Professionalism, Quality of Service, Hotel

Abstrak: Yogyakarta sebagai salah satu bagian dari Negara Indonesia mempunyai potensi yang cukup besar untuk ikut berperan dalam pengembangan wisata di Indonesia. Di tengah kompetisi global saat ini penting bagi setiap karyawan hotel untuk meningkatkan pelayanan agar dapat bersaing dengan hotel lainnya. Apa yang perlu dilakukan oleh manajemen hotel saat ini adalah meningkatkan kualitasnya melalui upaya meningkatkan profesionalisme karyawan agar tamu merasa puas dan loyal. Profesi yang saat ini digenjot oleh Kemenpar bekerjasama dengan Lembaga Sertifikasi Profesi (LSP) untuk melakukan uji kompetensi, salah satunya adalah hotel. Rumusan masalah yang dapat ditarik dari penelitian ini adalah bagaimana upaya peningkatan profesionalisme karyawan untuk meningkatkan kualitas pelayanan di Abadi Hotel Jogja. Tujuan penelitian ini adalah untuk mengetahui bagaimana upaya peningkatan profesionalisme karyawan untuk meningkatkan kualitas pelayanan di Abadi Hotel Jogja. Metode penelitian yang digunakan dalam penelitian ini adalah metode penelitian deskriptif kualitatif. Upaya peningkatan profesionalisme karyawan di Abadi Hotel Jogja adalah dengan pemberian beasiswa pendidikan yaitu karyawan yang berprestasi diberikan beasisawa untuk melanjutkan D3 bagi yang masih berijazah SMA, dan beasiswa untuk melanjutkan D4/S1, mengadakan pelatihan yang diadakan di Abadi Hotel Jogja yaitu training UP selling, peningkatan skill, pengembangan SDM, Grooming, Attitude, Handling Complain, Leadership dan Skill Communication, Making Bed, Step by step dusting procedure, How to cleaning the bathroom, How to vacuum swimming pool, How to prepare room boy cart, Entering the guest room, Check room status, How to cleaning glasses, How to cleaning furniture, How to linen safety, How to pick up \& delivery guest laundry, Refresh billing system, penerapan Standar Operasional Prosedur (SOP) dan action plan yang diberikan oleh para ahli sesuai dengan bidangnya yaitu dosen APMD, praktisi dari Hotel Hyatt, TVRI, para pakar pariwisata, dan intern dari HRD serta berkunjung ke Hotel lain untuk belajar, serta melaksanakan sertifikasi kompetensi bagi karyawan untuk menetapkan bahwa seseorang memenuhi persyaratan kompetensi yang ditetapkan melalui kerjasama dengan LSP Pariwisata Cabang DIY.

Kata Kunci: Profesionalisme Karyawan, Kualitas Pelayanan, Hotel 


\subsection{Latar Belakang}

Pembangunan di sektor pariwisata selain dapat meningkatkan penerimaan devisa, pembangunan pariwisata juga diharapkan dapat memberikan dampak-dampak positif, yaitu peningkatan pendapatan masyarakat sekitar, peningkatan kesempatan kerja, dan peluang usaha sehingga kesejahteraan masyarakat akan meningkat. Yogyakarta sebagai salah satu bagian dari Negara Indonesia mempunyai potensi yang cukup besar untuk ikut berperan dalam pengembangan wisata di Indonesia. Yogyakarta adalah kota yang sangat menarik. Banyak predikat melekat pada Daerah Istimewa ini. Jogja sebagai kota perjuangan, kota budaya, kota pendidikan dan juga Kota wisata. Orang yang tinggal di kota ini berasal dari beragam bangsa, baik Warga Negara Indonesia (WNI) maupun Warga Negara Asing (WNA).

Faktor penunjang sektor pariwisata yang paling penting adalah hotel. Sebagai penjual jasa pelayanan, hotel perlu menyediakan tiga hal, yaitu fasilitas yang memadai untuk melayani pemakai (tamu), Sumber Daya Manusia yang terampil untuk melayani tamu, dan manajemen pengelolaan yang profesional (Soewirjo, 2008). Hotel sebagai salah satu lembaga yang bersifat profit tentu saja harus memperhatikan faktor Sumber Daya Manusianya. Abadi Hotel Jogja merupakan salah satu manajemen perusahaan di bidang pariwisata yaitu jasa perhotelan yang memperhatikan pendidikan karyawannya untuk dapat meningkatkan profesionalisme kerjanya.

Sebagian besar karyawan Abadi Hotel Jogja mempunyai latar pendidikan SMA dan sederajad. Dalam menghadapi persaingan di dunia bisnis perhotelan, pendidikan dan pelatihan karyawan harus diperhatikan untuk meningkatkan profesionalismenya. Berdasarkan wawancara dengan manajemen Abadi Hotel Jogja, untuk mendukung pengetahuan karyawan melalui pendidikan, pihak manajemen hotel juga memberikan pelatihan, akan tetapi pelatihan yang diberikan belum maksimal karena apabila tidak didasari oleh pendidikan yang cukup, pelatihan tersebut tidak dapat diterima dengan baik. Pelatihan yang diberikan selama ini adalah training up selling, grooming, attitude, handling complain, leadership, dan skill communication. Apabila pendidikan karyawan sudah mencukupi, pelatihan dapat diperluas lagi agar tujuan perusahaan dapat tercapai. Selain pendidikan, tuntutan dunia kerja saat ini memaksa karyawan memiliki kompetensi dan akselerasi teknologi yang sangat cepat sesuai dengan standar yang diminta oleh pasar industri.
Kenyataannya kesenjangan kompetensi yang diajarkan/dilatihkan pada peserta didik masih jauh dari harapan kualifikasi kompetensi pihak industri. Profesi-profesi yang saat ini digenjot oleh Kemenpar bekerjasama dengan LSP untuk melakukan uji kompetensi adalah hotel dan restoran, pemandu perjalanan wisata, pelaku spa, jasa boga, tour leader, pemandu ekowisata, Mice, pemandu arung jeram, pemandu selam, pemandu museum, dan pemandu out bond. http://m.suarakarya.id/2016/03/07/sdmpariwisata-harus-ikut-uii-kompetensi 29 DES 2016.

Di tengah kompetisi global dan regional saat ini penting bagi setiap SDM untuk tetap aktif mendorong peningkatan pelayanan agar dapat memenangkan persaingan dengan hotel lain. Apa yang perlu dilakukan oleh setiap hotel saat ini adalah secara serius meningkatkan kualitasnya secara bertahap. Tugas Manajemen hotel tidak hanya membenahi kualitas fisiknya saja namun harus terus meningkatkan kualitas non fisiknya. Karyawan hotel yang tersertifikasi dapat meningkatkan kinerja, diharapkan juga dapat membantu mengontrol kualitas layanan yang diberikan kepada tamu. Kompetensi SDM sangatlah penting untuk menjamin kepercayaan konsumen. Hotel dalam standar usaha hotel berdasarkan Permen Parekraf No PM.53/HM.001/MPEK/2013 merupakan permen yang dijadikan dasar untuk mengukur sejauh mana hotel berada di standar bintang dan non bintang tertuang persyaratan mutlak karyawan hotel wajib bersertifikat kompetensi. Dari total 25 sub unsur dituangkan secara khusus 1 sub unsur yang mengenai sertifikasi kompetensi. Selain persyaratan mutlak, pada persyaratan tidak mutlak tertuang juga kewajiban hotel untuk memenuhi setidaknya 50 persen karyawannya memiliki sertifikat kompetensi. Dalam sub unsur tidak mutlak sertifikasi kompetensi dinilai dengan beberapa rentang nilai dengan ketentuan sebagai berikut: Kategori nilai 1, hotel melaksanakan sertifikasi kompetensi bekerjasama dengan LSP untuk departemen HK. Hotel memiliki $50 \%$ karyawan yang bersertifikat kompetensi dari jumlah karyawan. Kategori 2, Melaksanakan Sertifikasi kompetensi bekerjasama dengan LSP untuk beberapa departemen seperti FO dan HK. Hotel memiliki $50 \%$ karyawan yang bersertifikat kompetensi dari jumlah karyawan. Kategori nilai 3, melaksanakan sertifikasi kompetensi bekerjasama dengan LSP untuk beberapa departemen seperti FO, HK dan FB. Hotel memiliki $50 \%$ karyawan yang bersertifikat kompetensi dari jumlah karyawan. Kategori 
nilai 4, melaksanakan sertifikasi kompetensi bekerjasama dengan LSP secara terprogram untuk beberapa departemen, seperti FO, HK, FB dan kitchen. Hotel memiliki $50 \%$ karyawan yang bersertifikat kompetensi dari jumlah karyawan. Kategori nilai 5, melaksanakan sertifikasi kompetensi bekerjasama dengan LSP. Untuk mencapai hal tersebut perlu upaya manajemen meningkatkan profesionalisme karyawan.

Dari latar Belakang yang diuraikan di atas dapat ditarik rumusan masalah bagaimana upaya peningkatan profesionalisme karyawan untuk meningkatkan kualitas pelayanan di Abadi Hotel Jogja? Tujuan peneltian ini adalah untuk mengetahui bagaimana upaya peningkatan profesionalisme karyawan untuk meningkatkan kualitas pelayanan di Abadi Hotel Jogja. Manfaat teoritis dari penelitian ini adalah sebagai penambah ilmu pengetahuan tentang perhotelan terutama tentang profesionalisme karyawan. Manfaat Praktis dari penelitian ini adalah sebagai strategi manajemen dalam meningkatkan profesionalisme karyawan.

\subsection{Tinjauan Pustaka}

\subsubsection{Profesionalisme}

Profesionalisme berasal dari Bahasa Anglosaxon yang mengandung pengertian kecakapan, keahlian dan disiplin. Profesionalisme mengandung arti menjalankan suatu profesi untuk keuntungan atau sumber kehidupan. Kamus webster Amerika menegaskan bahwa profesionalisme adalah suatu tingkah laku suatu tujuan atau rangkaian kualitas yang menandai atau melukiskan coraknya (Anoraga, 2009). Menurut Anoraga (2009) beberapa ciri profesionalisme yaitu:

1. Profesionalisme menghendaki sifat mengejar kesempurnaan hasil sehingga dituntut untuk selalu mencari peningkatan mutu.

2. Profesionalisme memerlukan kesungguhan dan ketelitian kerja yang hanya dapat diperoleh melalui pengalaman dan kebiasaan.

3. Profesionalisme menuntut ketekunan dan ketabahan, yaitu sifat tidak mudah puas atau putus asa sampai hasil tercapai.

4. Profesionalisme memerlukan integritas tinggi yang tidak tergoyahkan oleh keadaan terpaksa atau godaan iman.

5. Profesionalisme memerlukan adanya kebulatan fikiran dan perbuatan, sehingga terjaga efektivitas kerja yang tinggi.

\subsubsection{Kompetensi}

Dunia kerja mempersyaratkan berbagai standar kompetensi yang harus dipenuhi. Standar kompetensi tersebut sangat erat berkaitan dengan kompetensi kerja yang nyata. Dalam hal ini Direktorat Pembelajaran dan Kemahasiswaan Direktorat Jenderal Pendidikan Tinggi tahun 2010/2011 telah mengkaji implikasi dan strategi implementasi Kerangka Kualifikasi Nasional Indonesia (KKNI). KKNI dimiliki oleh setiap Negara yang pada dasarnya merupakan Pemaketan Unit Kompetensi. KKNI inilah yang menjadi pedoman pengembangan kompetensi di lembaga pendidikan akademis. Sementara itu, untuk tembaga pelatihan/ kejuruan menurunkan pemaketan kompetensi tersebut dengan Standar Kompetensi Kerja Nasional Indonesia. Pengertian Kompetensi menurut UU No. 13/2003 tentang Ketenagakerjaan pasal 1 (10) Kompetensi adalah kemampuan kerja setiap individu yang mencakup aspek pengetahuan, keterampilan dan sikap kerja yang sesuai dengan standar yang ditetapkan. Kompetensi adalah kemampuan (melaksanakan tugas) yang dilandasi oleh pengetahuan (Knowledge), keterampilan (Skills) dan sikap kerja (Attitude) untuk menyelesaikan pekerjaan tertentu. Standar kompetensi merupakan kesepakatan tentang kompetensi yang dibutuhkan pada suatu bidang pekerjaan oleh seluruh Stake Holder atau perumusan tentang kemampuan yang harus dimiliki seseorang untuk melakukan pekerjaan yang didasari atas pengetahuan, ketrampilan dan sikap kerja sesuai dengan untuk kerja yang dipersyaratkan (SKKNI). Adapun elemen kompetensi pokok yang wajib dikembangkan dalam setiap proses pendidikan/pelatihan dapat dilihat pada gambar Elemen Kompetensi di bawah ini :

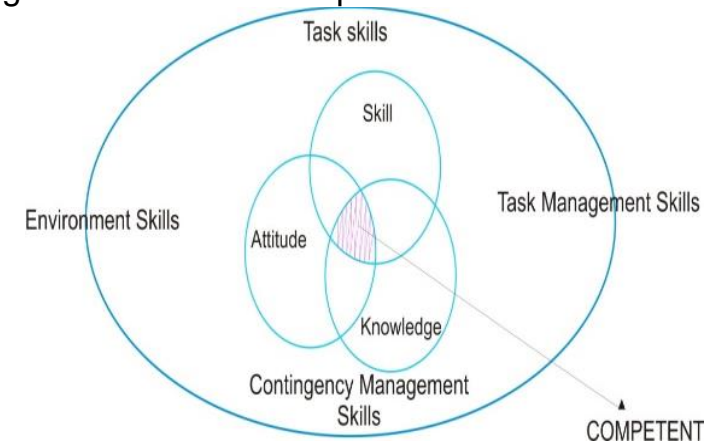

Sumber : Diktat competency, 2013.

Gambar 1. Elemen Kompetensi

Dari gambar elemen kompetensi di atas, masing-masing elemen dijelaskan sebagai berikut :

1. Task Skill merupakan kompetensi melaksanakan tugas individu (kemampuan melakukan tugas secara teknis profesional);

2. Task Management Skills merupakan kemampuan mengelola sejumlah tugas yang berbeda dalam satu pekerjaan; 
3. Contingency Management Skills merupakan kemampuan merespon dan mengelola kejadian ireguler dan masalah (kemampuan mengantisipasi masalah, dalam melaksanakan pekerjaan;

4. Job/Role Environment Skills merupakan kemampuan menyesuaikan dengan tanggung jawab dan harapan lingkungan kerja.

\subsection{Metodologi Penelitian}

Penelitian ini merupakan penelitian kualitatif. Kualitatif menurut Moleong (2012) pada dasarnya landasan teoritis dari penelitian kualitatif itu bertumpu secara mendasar pada fenomenologi. Karena itu pada bagian ini fenomenologi dijadikan sebagai dasar teoritis utama sedang yang lainya yaitu interaksi simbolik, kebudayaan, dan etnometodologi dijadikan sebagai dasar tambahan yang melatarbelakangi secara teoritis penelitian kualitatif. Sedangkan Menurut Sugiyono (2008) metode deskriptif adalah suatu metode yang digunakan untuk menggambarkan atau menganalisis suatu hasil penelitian tetapi tidak digunakan untuk membuat kesimpulan yang lebih luas. Teknik pengambilan data untuk memperoleh informasi dalam penelitian ini yaitu:

\section{Pengamatan}

Menurut Syaodih (2009: 220) observasi atau pengamatan merupakan suatu teknik atau cara mengumpulkan data dengan jalan mengadakan pengamatan terhadap kegiatan yang sedang berlangsung. Sedangkan menurut Sutrisno Hadi dalam Sugiyono (2008:145), observasi merupakan suatu proses yang kompleks, suatu proses yang tersusun dari berbagai proses biologis dan psikologis. Dua diantara yang terpenting adalah proses-proses pengamatan dan ingatan.

2. Wawancara

Menurut Fathoni (2006: 105) wawancara adalah tekhnik pengumpulan data melalui proses tanya jawab lisan yang berlangsung satu arah, artinya pertanyaan datang dari pihak yang mewawancarai dan jawaban diberikan oleh yang diwawancara. Wawancara adalah metode yang digunakan untuk memperoleh informasi secara langsung, mendalam bentuknya bisa terstruktur dan individual. Jadi dengan wawancara, maka peneliti akan mengetahui hal-hal yang lebih mendalam tentang partisipan dalam menginterpretasikan situasi dan fenomena yang terjadi, dimana hal ini tidak bisa ditemukan melalui observasi.

3. Dokumentasi
Menurut Fathoni (2006:112) studi dokumentasi ialah teknik pengumpulan data yang mempelajari catatan-catatan mengenai data pibadi responden, seperti yang dilakukan oleh seorang psikolog dalam meneliti perkembangan seorang klien melalui catatan pribadinya. Sedangkan menurut Sugiyono (2008:240) dokumen merupakan catatan peristiwa yang sudah berlalu. Dokumen bisa berbentuk tulisan, gambar, atau karyakarya monumental dari seseorang. Hasil penelitian akan lebih kredibel apabila didukung oleh foto-foto atau karya tulis akademik dan seni yang telah ada.

4. Studi Pustaka

Penulis memperoleh data dengan berbagai macam literature. Tujuannya untuk memperoleh data penjelasan yang lebih tepat dan akurat yang akan digunakan sebagai penunjang penelitian khususnya sebagai dasar dari landasan teori yang dapat dipertanggungjawabkan sumbernya.

\subsection{Hasil Penelitian Dan Pembahasan}

Upaya peningkatan profesionalisme karyawan di Abadi Hotel Yogyakarta dilakukan melalui beberapa kebijakan yaitu:

\subsubsection{Pendidikan}

Manajemen memberikan kesempatan melalui pendidikan kepada karyawan agar dapat bersaing di dunia perhotelan. Selain itu perusahaan juga selalu berusaha membangun penambahan kamar agar karyawan lebih sejahtera dan memberikan kesempatan kepada karyawan untuk mengembangkan karirnya. Seorang karyawan dalam pekerjaannya tentu saja memperoleh penilaian kerja melalui prestasi kerjanya. Semakin tinggi prestasi kerja seorang karyawan maka dapat dikatakan bahwa semakin tinggi pula kualitas karyawan tersebut untuk dapat mengembangkan karirnya. Agar tujuan perusahaan tercapai, maka diharapkan terjadi hubungan yang harmonis dari pihak atasan dan bawahan melalui program dari perusahaan yang mendukung. Pada dasarnya pendidikan dan pelatihan merupakan proses yang berlanjut dan bukan proses sesaat saja terutama disaat perkembangan pengetahuan dan teknologi yang berkembang pesat seperti saat ini, peran pendidikan dan pelatihan sangat besar untuk membekali karyawan agar lebih kreatif dalam mencapai tujuan perusahaan secara efektif dan efisien. Secara umum tujuan pelaksanaan pendidikan dan pelatihan adalah memperbaiki efektifitas dan efisiensi kerja karyawan dalam melaksanakan dan mencapai sasaran program-program kerja yang telah ditetapkan. Semakin baik program 
pendidikan dan pelatihan yang dilakukan oleh manajemen maka semakin mahir karyawannya dalam menyelesaikan pekerjaan. Pendidikan karyawan di Abadi Hotel Jogja dapat dilihat dalam tabel di bawah ini:

Tabel 1. Pendidikan karyawan Abadi Hotel

\begin{tabular}{|c|c|c|}
\hline \multicolumn{3}{|c|}{ Jogja } \\
Pendidikan & Jumlah & Persentase \\
\hline SMA/K & 55 & $55 \%$ \\
D1 & 7 & $7 \%$ \\
D2 & 1 & $1, \%$ \\
D3 & 32 & $32 \%$ \\
S1 & 5 & $5 \%$ \\
\hline Total & 100 & $100 \%$ \\
\hline
\end{tabular}

Sumber : Data primer yang diolah (2017)

Dari tabel di atas menunjukkan bahwa jumlah karyawan Abadi Hotel Jogja dengan pendidikan SMA/K memiliki prosentase tertinggi sebesar $55 \%$ sehingga pendidikan karyawan di Abadi Hotel Jogja masih perlu diperhatikan. Pendidikan merupakan suatu kegiatan untuk meningkatkan pengetahuan umum seseorang termasuk didalamnya peningkatan penguasaan teori dan keterampilan memutuskan terhadap persoalan-persoalan yang menyangkut kegiatan mencapai tujuan. Menurut manajemen Abadi Hotel Jogja, pendidikan berfungsi untuk menjembatani kesenjangan antara kemampuan individu dengan kebutuhan pekerjaan di Abadi Hotel Jogja. Pendidikan membantu karyawan dalam menghindarkan diri dari keusangan dan melaksanakan pekerjaan dengan baik. Manfaat yang diperoleh melalui pendidikan adalah sebagai berikut:

1. Pendidikan dapat memperbaiki cara kerja karyawan, sehingga cara kerja mereka tidak bersifat statis melainkan selalu disesuaikan dengan perkembangan organisasi.

2. Dengan pendidikan, karyawan dapat berkembang dengan cepat.

3. Dengan pendidikan, karyawan mampu bekerja lebih efektif dan efisien.

4. Dengan pendidikan, karyawan mampu melaksanakan tugas dengan lebih baik.

5. Pendidikan meningkatkan semangat kerja karyawan dan produktivitas perusahaan.

Pendidikan mencakup kegiatan-kegiatan yang diselenggarakan untuk meningkatkan kompetensi menyeluruh seseorang. Pendidikan ditujukan untuk memperbaiki kinerja pegawai dalam melaksanakan tugas yang dibebankan kepadanya. Pendidikan untuk karyawan juga mempunyai peranan untuk mendidik agar memiliki dasar-dasar karakteristik seorang tenaga kerja yang dibutuhkan, sedangkan pelatihan mempunyai karakteristik yang diinginkan oleh lapangan kerja. Pendidikan membentuk dan menambah pengetahuan seseorang untuk dapat mengerjakan sesuatu lebih cepat dan tepat, sedangkan latihan membentuk dan meningkatkan keterampilan kerja. Dengan demikian semakin tinggi tingkat pendidikan dan latihan seseorang semakin besar tingkat kinerja yang dicapai. Pendidikan berkaitan dengan mempersiapkan tenaga kerja yang diperlukan oleh suatu instansi atau organisasi dengan menekankan pada kemampuan kognitif, afektif dan psychomotor. Pendidikan dengan berbagai programnya mempunyai peranan penting dalam memperoleh dan meningkatkan kualitas kemampuan profesional individu. Melalui pendidikan seseorang dipersiapkan untuk memiliki bekal agar siap, mengenal dan mengembangkan metode berfikir secara sistematik agar dapat memecahkan masalah yang akan dihadapi dalam pekerjaan.

Dalam peningkatan kemampuan kognitif, afektif dan psychomotor serta peningkatan profesionalisme karyawan, manajemen Abadi Hotel Jogja memberikan beasiswa bagi karyawan yang berprestasi untuk melanjutkan D3 dan S1. Dengan karyawan yang berpendidikan tinggi, maka profesionalisme karyawan juga akan meningkat. Hal tersebut dapat dilihat dari penilaian prestasi kerja sesudah dan sebelum ada program pendidikan. Sebelum ada program pendidikan, kesadaran karyawan masih kurang yaitu karyawan sering terlambat, kepribadian dalam bersikap masih sering dilandasi dengan emosi, tanggung jawab terhadap terselesaikannya pekerjaan masih kurang karena terburu buru cepat pulang dan kerjasamanya masih kurang karena ingin menonjolkan kemampuan diri sendiri. Setelah ada program pendidikan, karyawan dapat membentuk teamwork yang solid, saling membantu, prosentase keterlambatan berkurang, jujur dan bertanggung jawab terhadap pekerjaannya serta memiliki loyalitas kerja yang tinggi. Setelah lulus D3, saat ini juga ada 2 karyawan Abadi Hotel Jogja yang diberikan subsidi pendidikan untuk melanjutkan kuliah D4 di STP AMPTA.

\subsubsection{Pelatihan}

Di dalam perkembangan dunia industri perhotelan, karyawan Abadi Hotel Jogja harus mengikuti kemajuan ilmu pengetahuan dan teknologi (IPTEK). Sedangkan sebagai bentuk perwujudan sumber daya manusianya untuk menguasai kegiatan dunia perhotelan, sebagai pelaku maka diperlukan suatu penuntun, yaitu berupa aturan, sistem, manajemen, dan tata kelola lainnya yang direkam dalam bentuk 
buku-buku, media cetak, media audio, media visual serta media lainnya. Untuk meningkatkan sumberdaya yang cakap dalam IPTEK di berbagai departemen di Abadi Hotel, pihak manajemen mengadakan pelatihan.

$\mathrm{Di}$ industri pelayanan, dikenal adanya industri tangible sebagai industri nyata serta dapat dilihat dan intangible sebagai industri tidak nyata tetapi dapat dirasakan. Dalam industri intangible, perilaku manusia menjadi dominan dalam pelaksanaan kegiatan di hotel. Tamu akan mengenal senyuman, keramahtamahan, sopan santun dan ucapan selamat datang yang hanya berasal dari karyawan. Hal ini yang menjadikan manusia menjadi unsur yang dominan dalam pekerjaan di industri perhotelan. Agar karyawan dapat melaksanakan tugas pelayanan dalam pekerjaannya membutuhkan adanya pelatihan kerja. Hal ini disadari untuk menghindarinya adanya tumpang tindih dari masing-masing peran individu dan menghindari adanya benturan-benturan kepentingan setiap bagian di dalam satu organisasi.

Meskipun usaha-usaha pelatihan memakan waktu dan memerlukan biaya yang mahal, akan tetapi manfaatnya besar sekali terhadap keberlangsungan perusahaan, karena akan mengurangi perputaran tenaga kerja dan membuat karyawan menjadi lebih produktif dan professional. Orientasi kerja harus diberikan kepada karyawan baru. Hal ini didasarkan pertimbangan, bahwa sebelum bekerja mereka perlu diperkenalkan kepada pimpinan, rekan sekerja, lingkungan kerja, jenis-jenis pekerjaan yang akan segera dijalani, peralatan yang digunakan, struktur organisasi dan fungsi masing-masing bagian. Dengan demikian karyawan tersebut tidak akan merasa canggung untuk beradaptasi dengan dunianya. Di Abadi Hotel Jogja program latihan yaitu: Metode praktis (on the job training), dan Teknik-teknik presentasi informasi dan metode-metode simulasi (off the job training).

Masing-masing jenis program latihan tersebut mempunyai sasaran pengajaran sikap, konsep atau pengetahuan dan keterampilan utama yang berbeda. Training yang diadakan di Abadi Hotel Jogja adalah training UP selling, peningkatan skill, pengembangan SDM, Grooming, Attitude, Handling complain, Leadership dan skill communication, Making Bed, Step by step dusting procedure, How to cleaning the bathroom, How to vacuum swimming pool, How to prepare room boy cart, Entering the guest room, Check room status, How to cleaning glasses, How to cleaning furniture, How to linen safety, How to pick up \& delivery guest laundry, Refresh billing system. Training tersebut diberikan oleh para ahli yang sesuai bidangnya, yaitu Dosen APMD, praktisi dari Hotel Hyatt, TVRI, para pakar pariwisata, dan intern dari HRD serta berkunjung ke Hotel lain untuk belajar. Dalam penelitian ini, pemberian training tersebut sangat efektif dan dapat meningkatkan profesionalisme kerja. Dengan adanya pelatihan, kemampuan karyawan dalam berbahasa inggris meningkat, kemampuan memasarkan produk jasa hotel semakin meningkat dapat terbukti bahwa kondisi kamar selalu penuh, tingkat kerusakan peralatan menjadi berkurang karena karyawan sudah semakin trampil dalam menggunakan alat serta tidak terjadi double booking karena karyawan sudah mahir mengoperasikan reservasi online.

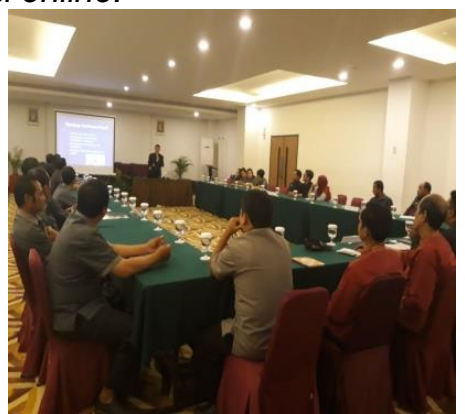

Sumber: Abadi Hotel Jogja (20018) Gambar 2. Training Karyawan

\subsubsection{Penerapan Standar Operasional Prosedur dan Pembuatan Action Plan Kejelasan manajemen membuat} karyawan antusias untuk melaksanakan peran tugasnya masing-masing. Adanya kejelasan organisasi sebagai upaya pelaksanaan peran tugas tersebut memiliki arah dan tujuan yang jelas perlu dibuatkan suatu pedoman baku dan standar berupa uraian tugas pekerjaan yang biasa disebut job description. Sementara implementasi pelaksanaan, uraian tugas pekerjaan juga harus diimbangi dengan standar operasional prosedur (SOP) pekerjaan. Untuk meningkatkan ketrampilan karyawan, manajemen Abadi Hotel Jogja juga membuat action plan untuk mengadakan training karyawan. Karyawan yang mengikuti training dengan sungguh sungguh serta bekerja sesuai dengan SOP tentu saja akan mempunyai profesionalisme kerja yang tinggi karena ketrampilan karyawan dalam pekerjaannya akan meningkat. Berikut Action Plan Front Office di Abadi Hotel Jogja:

\section{Action Plan Front Office Department Abadi Hotel Jogja \\ Divisi: Optimalisasi Profitabilitas}

\section{STRATEGI / TINDAKAN}




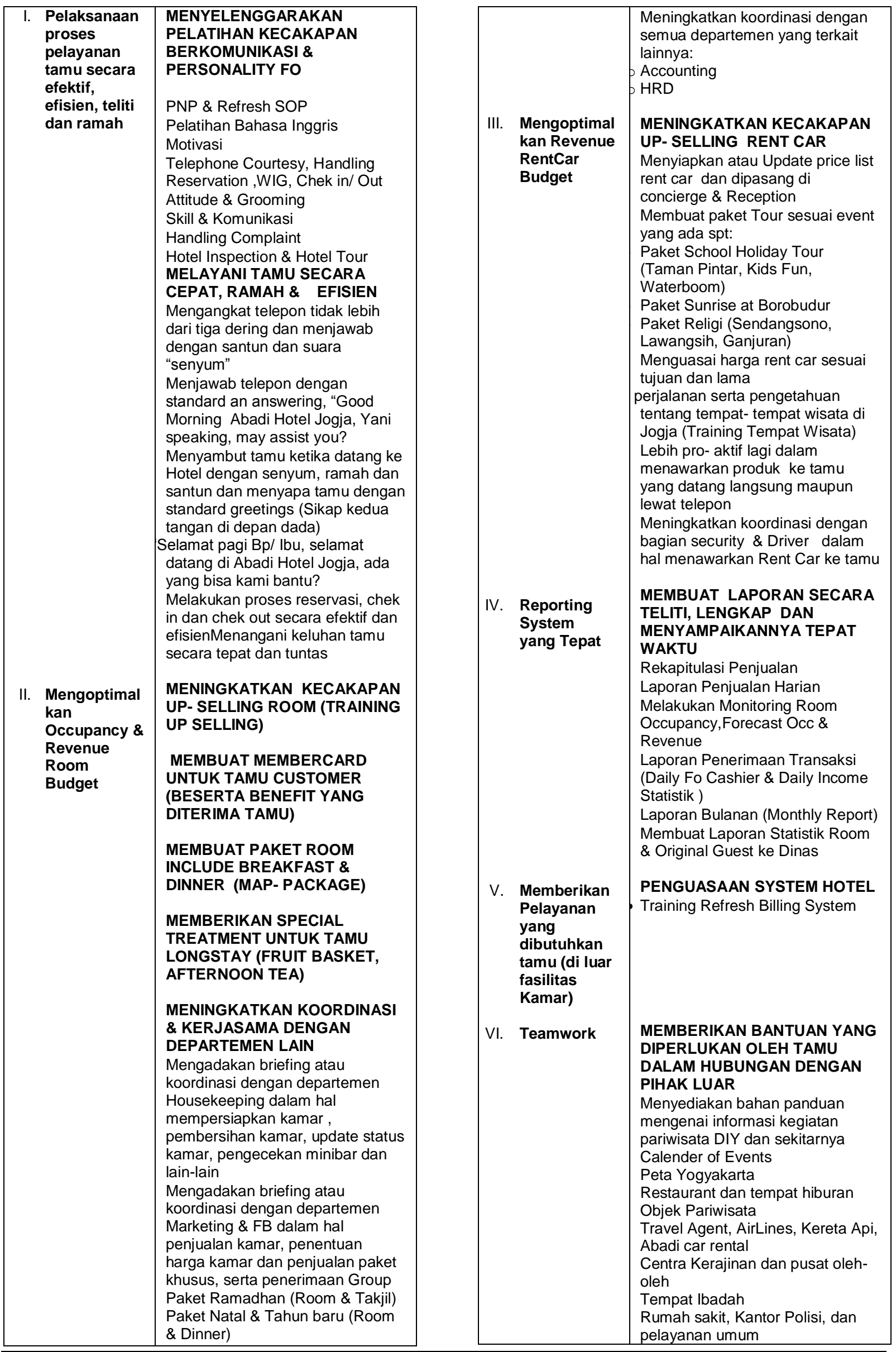




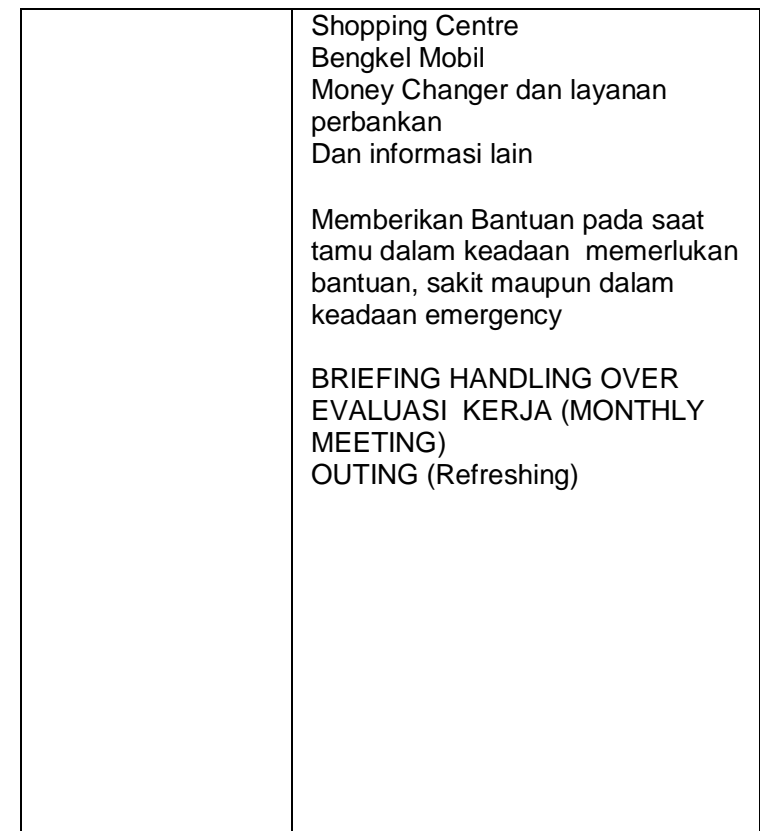

Sumber: Abadi hotel Jogja (2017)

\subsubsection{Sertifikasi Kompetensi}

Sertifikasi merupakan suatu proses untuk mendapatkan pengakuan resmi (keabsahan) atas produk, proses, keterangan, kepemilikan barang, atau orang. Sertifikasi untuk orang diberikan karena yang bersangkutan mempunyai kompetensi atas suatu tugas/pekerjaan/jabatan. Proses ini dikenal juga dengan sertifikasi kompetensi. Bila yang bersangkutan telah mendapatkan pengakuan atas kompetensinya, maka ia akan mendapatkan sertifikat kompetensi.

Seluruh kegiatan yang dilakukan oleh Lembaga Sertifikasi Profesi (LSP) untuk menetapkan bahwa seseorang memenuhi persyaratan kompetensi yang ditetapkan, mencakup permohonan, evaluasi, keputusan sertifikasi, survailen dan sertifikasi ulang, serta penggunaan sertifikat. Sertifikasi kompetensi kerja adalah proses pemberian sertifikat yang dilakukan secara sistematis dan objektif melalui assessment kompetensi kerja nasional Indonesia dan/atau internasional. Abadi Hotel Jogja bekerjasama dengan LSP Pariwisata Cabang DIY bertempat di Abadi Hotel JI Pasar Kembang Yogyakarta melakukan uji kompetensi untuk karyawan. Abadi Hotel Jogja telah memperoleh piagam tenaga kerja telah bersertifikasi. General Manager abadi Hotel menyampaikan bahwa sertifikasi kompetensi memberikan nilai tambah pada pengelolaan Abadi Hotel Jogja. Dengan karyawan yang tersertifikasi selain meningkatkan profesionalisme juga dapat meningkatkan kualitas pelayanan yang diberikan kepada tamu sehingga banyak tamu yang akhirnya menjadi pelanggan.

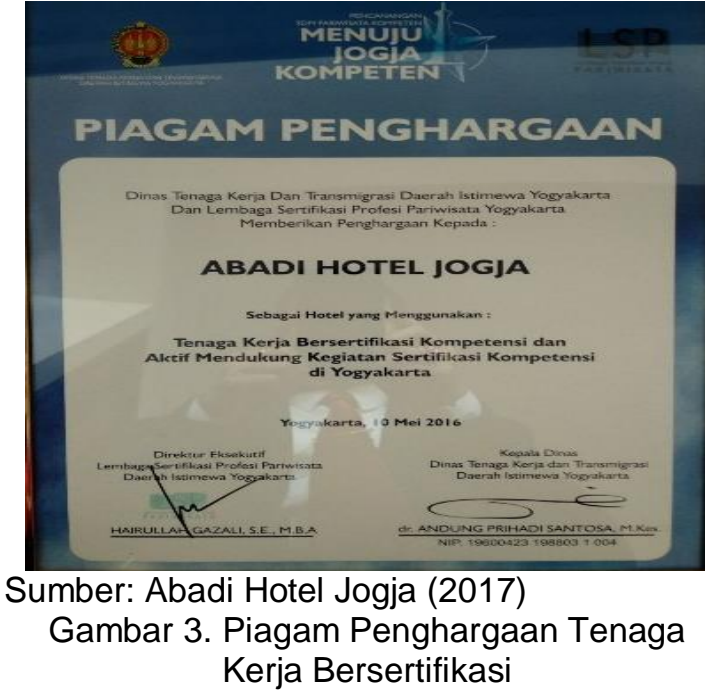

\subsection{Kesimpulan Dan Saran}

\subsubsection{Kesimpulan}

Peningkatan Prestasi Kerja karyawan

Abadi Hotel Jogja melalui:

1. Pendidikan

Dalam peningkatan kemampuan kognitif, afektif dan psychomotor serta peningkatan profesionalisme karyawan, manajemen Abadi Hotel Jogja Memberikan beasiswa bagi karyawan yang berprestasi untuk melanjutkan ke D3 dan D4/ S1.

2. Pelatihan

Dengan adanya pelatihan, kemampuan karyawan dalam berbahasa inggris meningkat, kemampuan memasarkan produk jasa hotel semakin meningkat dapat terbukti bahwa kondisi kamar selalu penuh, tingkat kerusakan peralatan menjadi berkurang karena karyawan sudah semakin trampil dalam menggunakan alat serta tidak terjadi double booking karena karyawan sudah mahir mengoperasikan reservasi online.

3. Penerapan SOP dan Action Plan

Karyawan yang mengikuti training dengan sungguh sungguh serta bekerja sesuai dengan SOP tentu saja akan mempunyai profesionalisme kerja yang tinggi karena ketrampilan karyawan dalam pekerjaannya akan meningkat.

4. Sertifikasi kompetensi

Abadi Hotel Jogja telah memperoleh piagam tenaga kerja telah bersertifikasi. Sertifikasi kompetensi memberikan nilai tambah pada pengelolaan Abadi Hotel Jogja. Dengan karyawan yang tersertifikasi selain meningkatkan profesionalisme juga dapat meningkatkan kualitas pelayanan yang diberikan kepada tamu.

\subsubsection{SARAN}

Program beasiswa pendidikan dan pelatihan sebaiknya dilakukan secara 
berkelanjutan supaya semakin banyak karyawan yang berpendidikan tinggi semakin trampil dalam memberikan pelayanan kepada tamu.

\section{Daftar Pustaka}

[1] Anoname. 2013. Materi Diklat Competency Based Training. Bali.

[2] DIKTI. 2011. Kerangka Kualifikasi Nasional Indonesia (KKNI). Jakarta: DIKTI

[3] Anoraga, Pandji. 2009. Manajemen Bisnis. Jakarta : PT. Rineka Cipta.

[4] Fathoni, Abdurrahmat. 2006. Metodologi Penelitian dan Teknik Penyusunan Skripsi. Jakarta: PT Rineka Cipta.
[5] Moleong L.J. 2012. Metodologi Penelitian Kualitatif. Bandung: Remaja Rosda Karya.

[6] Permen

Parekraf PM.53/HM.001/MPEK/2013

[7] Soewirjo, Herdi S. 2008. Teori \& Praktik Perhotelan. Yogyakarta: Andi.

[8] Syaodih, Nana. 2009. Metode Penelitian Pendidikan. Bandung: Rosda Karya.

[9] Sugiyono. 2008. Metode Penelitian Kuantitatif dan R\&D. Bandung: Alfabeta.

[10] http://m.suarakarya.id/2016/03/07/sdmpariwisata-harus-ikut-uii-kompetensi 29 Des 2016 